\title{
Following the Tracks of the First South Americans
}

\author{
Cristina Bayón • Teresa Manera • Gustavo Politis • \\ Silvia Aramayo
}

Published online: 5 May 2011

(C) Springer Science+Business Media, LLC 2011

\begin{abstract}
In this article, a summary of the geologic, paleontological, and human history of an area of the Atlantic coast in the Pampean plain, Argentina is discussed. This area presents very interesting characteristics. On the one hand, the area includes the Monte Hermoso cliffs studied by Charles Darwin in 1832, which compose the set of localities related to the development of the theory of evolution. On the other hand, in the referred area, an extraordinary amount of human and Pleistocene mammal footprints are registered. Also in that section, four diachronic stages have been registered which depict the evolutionary scenario during the last five million years. Four paleontological and archeological sites are described, showing the palaeoenvironmental changes that occurred there regarding fauna associations and human settlement. The first scenario is found at Monte Hermoso cliff, whose sediments contain fossil remains of the autochthonous South American fauna. The second scenario shows a remarkable change in the drainage system where the fauna is composed of immigrated taxa due to the Great American Biotic Interchange. Both last scenarios show human
\end{abstract}

\section{Bayón $(\bowtie)$}

Departamento de Humanidades, Universidad Nacional del Sur, 12 de octubre and San Juan,

8000, Bahía Blanca, Argentina

e-mail: crisbayon@gmail.com

T. Manera $\cdot$ S. Aramayo

Departamento de Geología, Universidad Nacional del Sur, San Juan 670,

8000, Bahía Blanca, Argentina

G. Politis

CONICET-INCUAPA, Facultad de Ciencias Sociales, UNCPBA, Av. del Valle 5737,

7400, Olavarría, Argentina presence; the third one shows faint evidences (one human trackway and two isolated footprints), and in the last one the hunter-gatherers are fully represented as a wellestablished population on the Pampean coast during the Early Holocene, registered at La Olla and Monte Hermoso I sites. In this way, the sites summarized in this work allow the reconstruction of four remarkable evolutionary scenarios in South America, as regards landscapes, fauna associations, and human population.

Keywords Fossil mammal footprints · Pleistocene megamammal extinctions $\cdot$ Early peopling of South America $\cdot$ Holocene coastal adaptations

\section{Introduction}

The aim of this article is to present a summary and a panoramic view of the geologic, paleontological, and human history of an area of 30 kilometers on the Atlantic coast in the southwest of the Argentinean Pampean plain between $32^{\circ}$ and $40^{\circ}$ south latitudes (Fig. 1). This is an area on the coast in which the natural outcrops and the discovery of fossils, human bones, tools, and footprints from animals and humans illustrate the evolution of life in the region from the Upper Tertiary to the Middle Holocene. This long history of five million years was recorded in an extraordinary way in four diachronic moments which reflect different scenarios with different environmental conditions and protagonists. Each of them shows the species typical of that moment, within different landscapes, shaped by the climatic changes. Human beings appear in the last two scenarios; first, in Pehuen Co site at the end of the Pleistocene, leaving a still weak signal; and then as strong evidences in the sites of La Olla and Monte Hermoso I in 


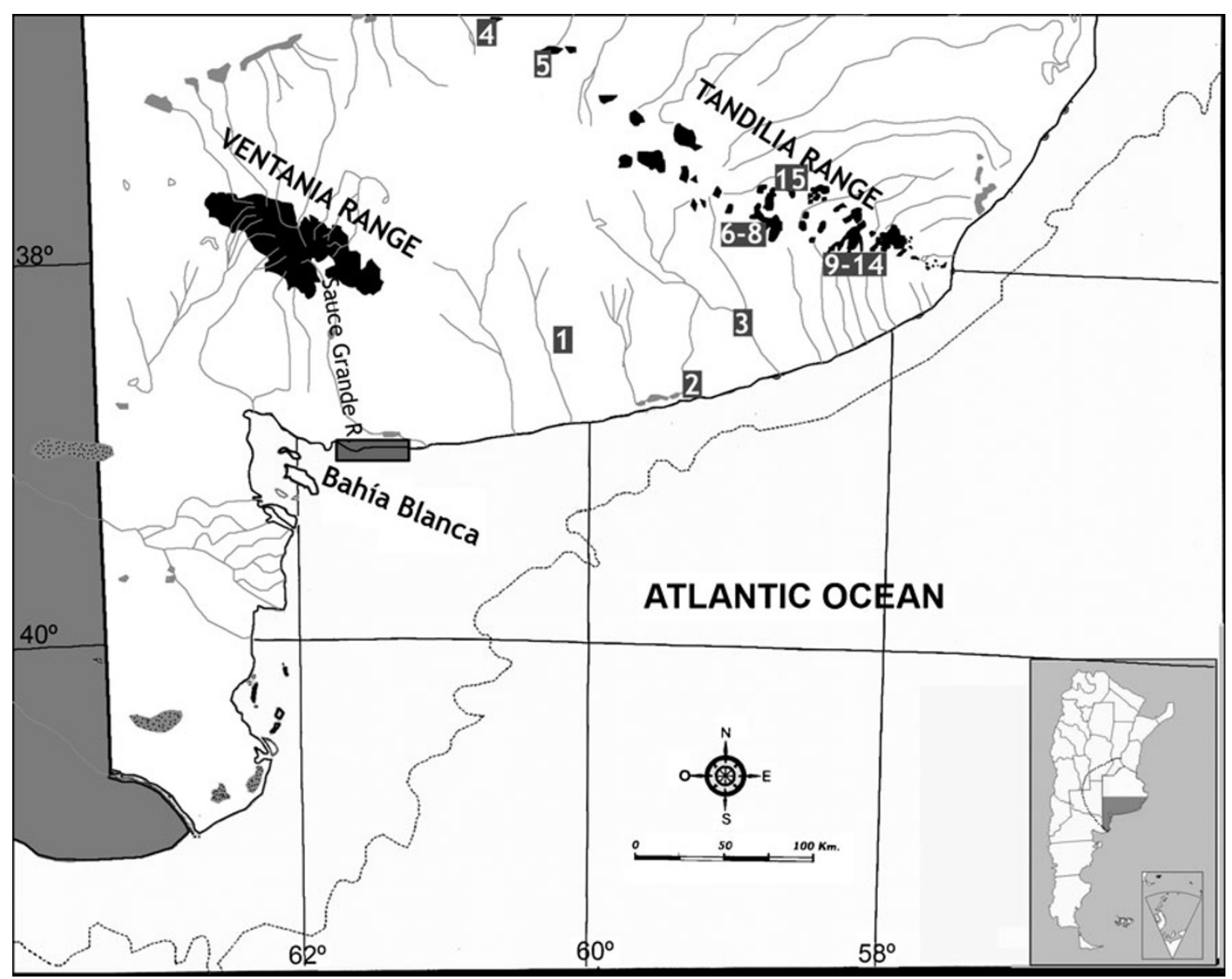

Fig. 1 Eastern Pampean Region map: archeological sites mentioned in the text: 1 Arroyo Seco 2 site; 2 El Guanaco 1 and 2 sites; 3 Paso Otero 5; 4 Campo Laborde; 5 La Moderna; 6 Los Helechos; 7 Cerro La China 1,2, and 3; 8 Cerro El Sombrero; 9 Cueva Tixi; 10 Burucuyá; 11 Los Pinos; 12 La Brava; 13 Cueva El Abra; 14 La

which the occupation of the sea coast by ancient Pampean hunter-gatherer groups during the Early and Middle Holocene is clearly recorded.

The sector of the coast analyzed in this review is the edge of a plain located between the Ventania hill range and the sea (Fig. 2). These hills act as dispersion centers of the pluvial water-forming rivers which flow from the hills of Ventania towards the Atlantic Ocean. The coastal area where these four scenarios are recorded is closely connected to the evolution of the lower valley of the Sauce Grande River, which is the most important river in the southwest of the Buenos Aires province. Nowadays, the river course is obstructed by a chain of coastal dunes, causing it to divert to the east, forming a small lake and flowing parallel to the line of dunes for 30 kilometers until reaching the sea.

The high number of either human or animal footprints is the most remarkable aspect of this group of archeological and paleontological sites. In spite of the extensive span of time considered and the geographic, climatic, and biolog-
Amalia; 15 Lobería 1. Limits of the studied area. - - - - - - - Coast in the Late Pleistocene (ca. 12,000 14 C yrs BP; taken from Flegenheimer et al. 2007). Current coast

ically important changes that occurred, the same formation conditions and erosive processes were amazingly repeated to allow the preservation and exposition of footprints of different origin and age.

A footprint or ichnite is a trace left on a soft substratum by an organism moving on it. However, in order to be preserved as a fossil footprint or ichnofossil, certain special conditions must be present. The substratum should be wet for the footprint to be imprinted; afterwards, it has to dry and be covered with sediment of different composition within a brief period of time. After thousands or millions of years, this substratum turns into a rather consolidated rock. The thinner the sediment grains, the better the footprint details are preserved. Also, the differences in lithology allow the formation of a weakness plane through which the rocks can be separated by the means of erosion, permitting the ichnite to be exposed and studied.

In the sector of the Atlantic coast summarized here, the presence of ichnites is complemented with another type of information; namely, synchronic and diachronic, which 


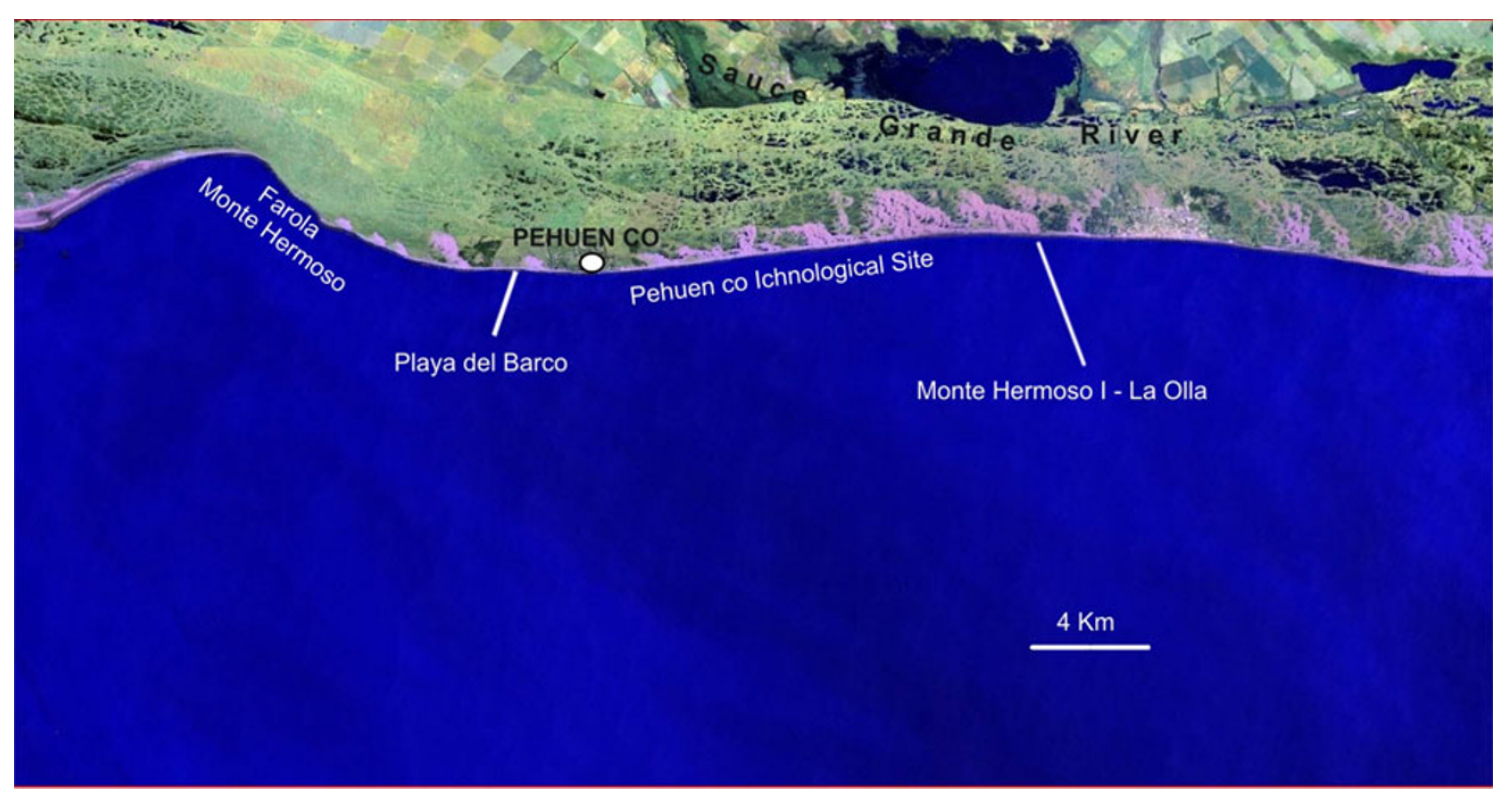

Fig. 2 Study area

allows a more precise reconstruction of the environmental and human history. These elements are outcrops exposed along many kilometers with Tertiary and Quaternary sediments, containing vertebrate fossils and stone, bone, and wooden tools of human populations who occupied the region since the Late Pleistocene.

\section{Historical Background}

The paleontological and archeological importance of the area treated here - mainly the Monte Hermoso cliff known today as Farola Monte Hermoso-has been recognized since the nineteenth century. In October 1832, Charles Darwin found the first fossil remains recovered from the lower layers of that fossiliferous locality, stratigraphically named Monte Hermoso Formation. A few days before, he had found in Punta Alta, about 50 kilometers to the west, fossil remains of large mammals that caught his attention remarkably (Megatherium, Mylodon, Toxodon). On Monte Hermoso cliff, he collected, along with some large mammal bones, several rodent remains including one of a cavid. Regarding this fossil, Eldredge (2009) points out:

With the Monte Hermoso fossil cavy, Darwin had direct evidence of the existence of an extinct species that had been replaced by a close relative still alive today. There can be no way of concluding with certainty that Darwin had by then become a 'transmutationist' but it is clear from his notes that he was actively contemplating the possibility as early as late 1832. Thus, I cannot help but think of Bahia Blanca as being as important to the development of Darwin's thinking as his much more famous visit to the Galapagos Islands three years later!

Fifty years later, that interest in Monte Hermoso cliff was revived by Florentino Ameghino, who considered that there was enough proof in the Monte Hermoso cliff to demonstrate the evolution of different mammals, including human beings. In 1887 , he stated that

Lo que aumenta extraordinariamente la importancia del yacimiento de Monte Hermoso, es la presencia del hombre conjuntamente con una fauna singular, revelada tanto por algunos pedernales y huesos toscamente tallados cuanto por la existencia de fogones en distintos niveles de la barranca, engastados en capas de arcilla, de los que con trabajo he podido arrancar fragmentos para llevar al Museo de La Provincia en La Plata [The importance of the Monte Hermoso deposit is the presence of man, together with such a singular fauna, both revealed in flints and bones grossly carved, the existence of campfires at different cliff levels and mounted in clay layers from which I was able to take fragments to take to the Museo de $\mathrm{La}$ Provincia en La Plata] (Ameghino 1887: 5/6).

Between 1906 and 1907, he made public the Tetraprothomo argentinus, which he considered to be an ancestor of humans. The remains found were a femur and an atlas; the first one was collected by Carlos Ameghino, while the atlas belonged to the Museo de La Plata collection (Pupio et al. 2009). Finally, in 1910, he published the finding of the oldest industry he recognized "la Industria de la Piedra Quebrada" (the broken stone industry), which he assigned to the Upper Miocene. During the Congreso Internacional 
de Americanistas, held in Buenos Aires in 1910, the Monte Hermoso cliff was visited by Aleš Hrdlička and Bailey Willis, who rejected Ameghino's propositions. The debate was fierce, and the site was repeatedly visited to clarify different aspects, such as stratigraphy and technology. The current knowledge about this geological, paleontological, and archeological site is presented in this article.

\section{The Scenarios and Evidence}

\section{The First Scenario: Farola Monte Hermoso}

The first scenario of this history is represented by MiocenePleistocene sediments that outcrop at the western end of the area considered in this article. This site, named Farola Monte Hermoso (FMH; Fig. 2), presents marine cliffs that reach 12 meters in height, along a stretch of more than three kilometers. At this site, one of the most important sequences for understanding the geologic evolution of the Pampean region during the Upper Miocene-Pliocene and Pleistocene crops out. The interpretation of the stratigraphy of the site has changed over time according to different authors, Zavala's (1993) explanation being the most accepted one (Fig. 3). According to Zavala, the stratigraphic sequence begins with fine sediments of the Monte Hermoso formation deposited on a fluvial environment of muddy and meandering rivers that flowed from eastnortheast to west-southwest and that were not connected to the history of Sauce Grande River.

These sediments contain vertebrate remains, particularly of Miocene-Pliocene mammals, members of the native fauna that lived in South America before the Great American Biotic Interchange. Among them, the marsupials were represented by some groups including Borhyaenids, which make their last appearance in the stratigraphic record. Other important representatives were the Xenarthra, both armadillos (Dasypodidae: i.e., Macroeuphractus and Chorobates; and Glyptodontidae: i.e., Plohophorus and Nopachthus) and ground sloths (Mylodontidae: i.e., Proscelidodon and Lestodon). Among the native ungulates, the remains of the Order Notoungulata are frequent, those of the Hegetotheridae, Mesotheriidae, and Toxodontidae families. Members of the two families of the Litopterna order, Protherotheriidae and Macraucheniidae (Promacrauchenia), are also found. There is also a varied representation of rodents corresponding to the second faunistic stratum of South America (Old Island Hoppers, Simpson 1950). Among them, species of Caviidae, Octodontidae, and Hydrochoeridae families are found. Freshwater fish, amphibious, reptile, and bird rests are present as well.

The mammal association of this site is extremely significative, and it is characteristic of a specific evolution- ary stage called Montehermosan Stage/Age (Marshall et al. 1983). Actually, this site is the archetype of this biostratigraphic unit. Although most of the fossils preserved here are bones, which have helped define the Stage/Age, there are also medium-sized footprints, which belong to ground sloths, characteristic members of the South American native fauna (Aramayo and de Manera Bianco 1996).

After a long period during which there was no sedimentary record, the Monte Hermoso Formation was topped with aeolian sandstones at the beginning of the Upper Pleistocene. These sediments compose the Puerto Belgrano Formation, formed in a dune and interdune environment (Zavala 1993). On top of this sandstone level, breccias and fluvial conglomerates were deposited, forming the Lower and Medium Members of the Punta Tejada Formation. These deposits are connected to the configuration of the fluvial valley related to the present Sauce Grande River. At that moment, the direction of the regional drainage changed, establishing it from Ventania to the Atlantic. The old Sauce Grande River flowed near the east end of the modern FMH cliff (Bayón and Zavala 1997).

The Upper Member of Punta Tejada Formation was assigned by Zavala (1993) as Lower/Middle Holocene. It is in this sandy deposit scattered with pebbles that quartzite flakes, cores and tools are found; Ameghino (1934 [1910]) assigned those remains to an exaggerated old tertiary age. Nowadays, we know it was a workshop where the fluvial pebbles of the Early Holocene mentioned above were used. Since the raw material was of medium quality for flaking, the Pampean hunter-gatherers invested little work on their manufacture (Bayón and Zavala 1997). The artifacts resemble rather crude-looking tools, and some of them are simply poorly flaked cores. This slight modification and its crudeness made Ameghino consider them to be "primitive" technology. On top of this sequence, the littoral dunes were set up, circa 7,000 years before present (BP), fixed today by vegetation typical of this landscape.

\section{The Second Scenario: Playa Del Barco}

The Playa del Barco site is located on the beach one kilometer to the west of Pehuen Co town. There, conglomerates and sandstones are found (Fig. 4). They are related to an old fluvial course of the Sauce Grande River, which by that time had migrated about 11 kilometers to the east of the Monte Hermoso cliff (Zavala and Quattrocchio 2001). These Late Pleistocene sediments contain mammal fossils of a more modern evolutionary stage than those from the Monte Hermoso Formation. So far, we are calculating with one radiocarbon measurement from macro-vegetable remains, which gives an age of $16.440 \pm 320$ years BP (Aramayo and de Manera Bianco 2000). 
Fig. 3 Monte Hermoso cliff (today known as Farola Monte Hermoso) (Stratigraphic section)

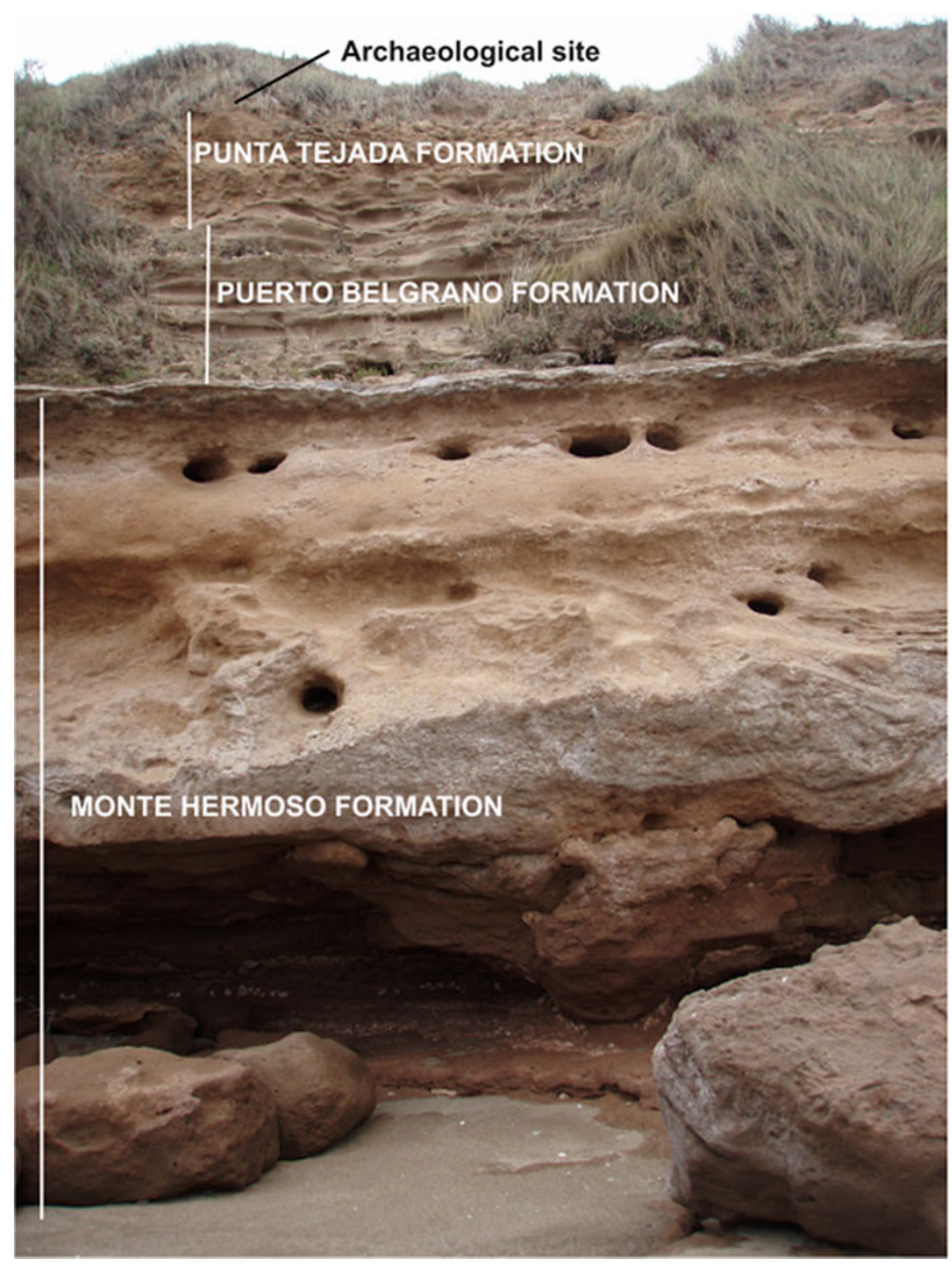

This faunal association contains members of the native fauna of either South and North America, composing a mixture post-Great American Biotic Interchange taxa. Representative species of the native fauna include some of the groups which were present at FMH but appearing as different, more modern genera: among the Xenarthra, the Dasypodidade with the genus Eutatus, and the Glyptodontidae with Glyptodon, Doedicurus, Panochthus, and others; the giant ground sloths with members of two families, Mylodontidae (Mylodon, Scelidotherium, Glossotherium) and Megatheridae (Megatherium). The endemic ungulates decreased notably in biodiversity and are only represented by one genus of the Notoungulata (Toxodon) and one of the Litopterna (Macrauchenia). The mammals of North American origin include Cervidae (Morenelaphus), Camelidae (Lama and Paleolama), Equidae, Proboscidea (Stegomastodon), and Carnivora (Smilodon; Aramayo and Manera de Bianco 1989). The studies carried out on this faunal group show that it was affected by taphonomic processes. The most remarkable process was the transportation of bones by a dense medium (debris flow), which affected the integrity of the group and produced a mixture of remains of different chronology and environments (Tomassini et al. 2010).

In addition to numerous bones, some footprints assigned to sloths and Macrauchenia were found in Playa del Barco (Fig. 5). Both of them are conspicuous members of the faunistic association of the Late Pleistocene. The layers where the ichnites were imprinted are clayey mudstones disposed on fluvial conglomerates.

The Third Scenario: Pehuen Co Palaeoichnological Site

By the end of the Pleistocene, about 12,000 radiocarbon years ago $\left({ }^{14} \mathrm{C}\right)$, the south Pampean landscape was noticeably different from the present one. The Atlantic coast was located 
Fig. 4 Playa del Barco Site. a Conglomerate outcrop near an old wreck. b A fossil deer jaw

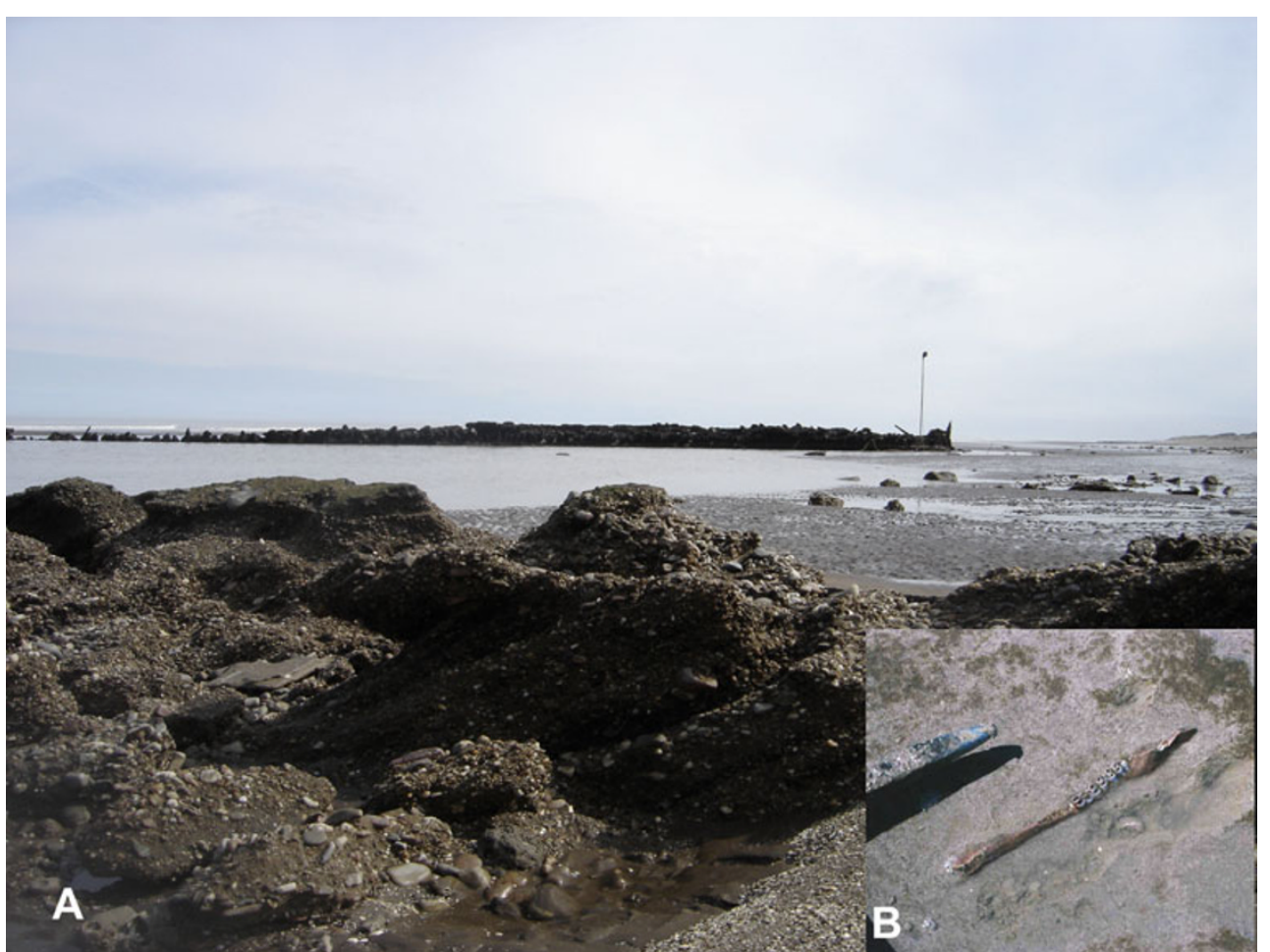

many hundred kilometers east due to a 100-meter lower sea level, a situation that caused an enlarging of the continental area. Climate conditions were extremely dry, cold, and windy (Quattrocchio et al. 2008). This produced an important change in the drainage system of the area. The rivers that nowadays drain their water from the hills of Ventania toward the Atlantic

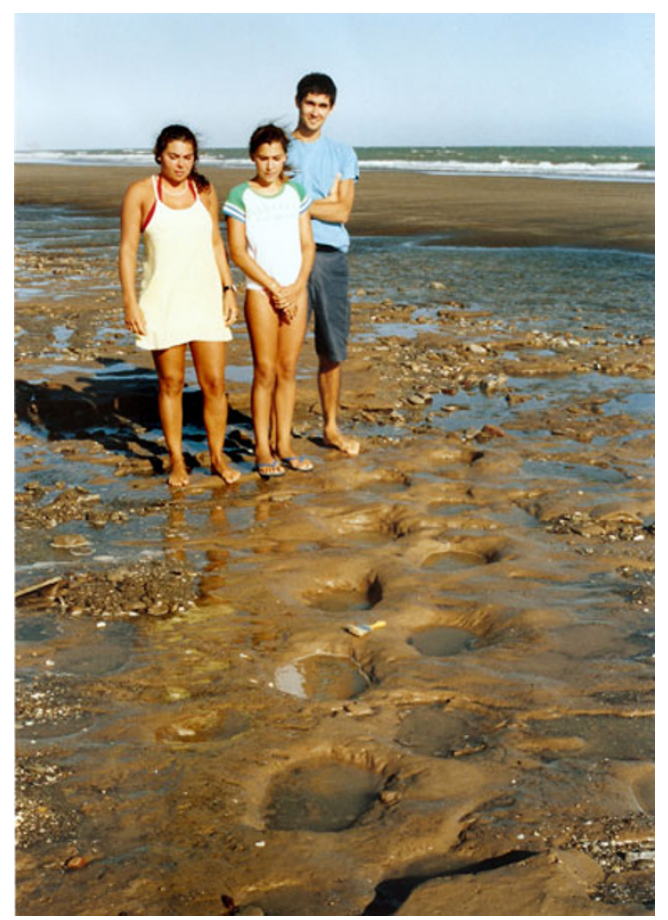

Fig. 5 Playa del Barco Site. Middle-sized ground sloth footprints
Ocean were not active. As a counterpart, an alternative drainage system was established with ephemerous watercourses that replaced the main fluvial system (Quattrocchio et al. 2009; Zavala et al. 2005). The water drained to the lower areas, forming temporary ponds. Those were the conditions present when the Pehuen Co palaeoichnological site was formed (Fig. 6), which in the local stratigraphy would correspond to the Middle Member of the Agua Blanca Sequence (Manera de Bianco et al. 2008). On the shores of these temporary ponds of the Pampean Late Pleistocene, an exceptional record of animal footprints and tracks crops out on platforms along 5,000 meters of the modern coast. The process was repeated quite regularly, each after a short period of time, generating overlapping layers.

The palaeoichnological record shows more than 100 trackways and hundreds of isolated footprints of different species. There are mammal ichnofossils of large animals, most of them extinct, and of medium-sized animals as well as of different birds that wandered along the pond shorelines. These footprints show that the represented fauna was very diverse and that it included the most conspicuous mammals of the South American Pleistocene fauna. This mammal association is rather similar to the one of Playa del Barco. The ichnogeneres described have been assigned to Megatheridae, Mylodontidae, Glyptodontidae, Macrauchenia, Paleolama, Lama, Equidae, Stegomastodon, Carnivora (Ursidae, Canidae, Felidae) and Caviidae (Fig. 7).

Up to the present, there is only one $14,000 \mathrm{BP}$ dating, based on organic matter recovered in the middle levels of the sedimentary sequence that contains the footprints of 

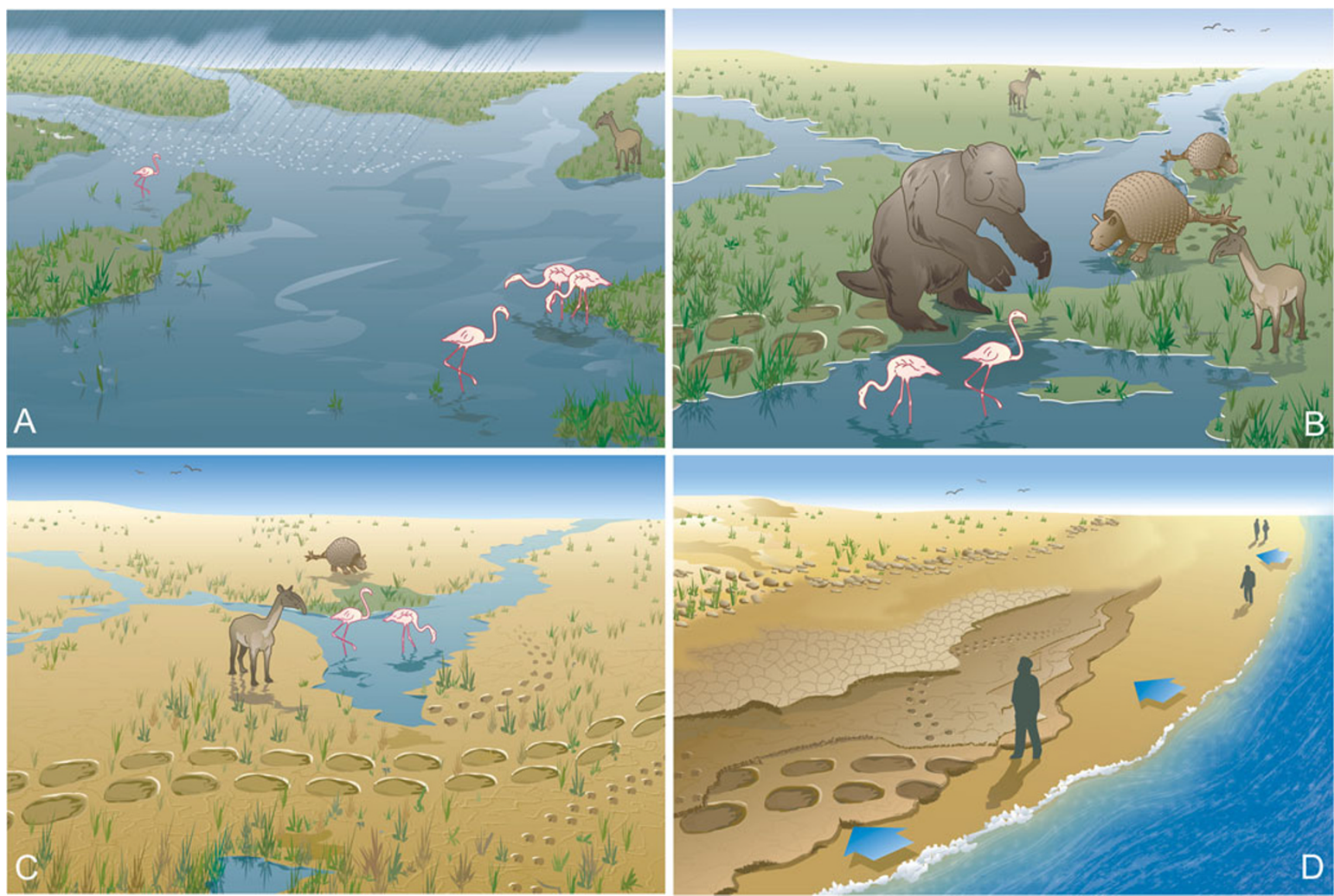

Fig. 6 Pehuen Co Palaeoichnological Site. a-c Formation stages of one layer bearing footprints. d Sketch of today's site (drawings by Léonie Schlosser (C) Rolex Awards)

the Pleistocene fauna. This dating produced an age of $12.000 \pm 110$ years BP, in coincidence with the chronologic estimations made as a result of the stratigraphic position of the faunistic group (Aramayo and de Manera Bianco 1996). Nevertheless, this age is still tentative due to the nature and uniqueness of the sample.

In 2005, new findings were made which also suggest the presence of human beings on the shores of these temporary ponds. So far, two types of signs of human presence have been found; namely, two isolated footprints and a trackway. The two isolated footprints were found on large pieces of clayey sediment separated from the layer by the tide. Each of them has a human footprint, in both cases of the left foot. In the sample PCO-05-1, there is a 23 centimeter-long footprint; the impression of the toes is indicated by a change of color in the sediment, and the big toe is better marked, with a depth of 0.7 centimeters. The second sample, PCO-05-01, exhibits a 23.5 centimeter-long trace with its lateral edges slightly deformed and with wellmarked toes. These pieces contain lithologic characteristics similar to the middle levels of the site, where numerous Megatherium, Macrauchenia, American horse, and guanaco footprints were found (Fig. 8).
The other evidence is a track of 13 consecutive footprints, with alternated traces of the right and left foot, as in a walking situation, and they correspond to only one individual (Fig. 9). The length of each footprint ranges between 33 and 35 centimeters, the maximum width between 13 and 15 centimeters, the depth between one and two centimeters, and the inter-step distance varying between 54 and 59 centimeters. None of the footprints have marks of toes. This situation could be the product of the use of some kind of footwear or because the sample is an undertrack. The latter happens when the thinner pelitic level where the footprint was produced has been eroded and only the weight deformation on an inferior layer is present. The assignment of this trace to human beings is based particularly on the angle between the footprints, which is $160^{\circ}$. This trace is located on one of the middle strata of the sedimentary sequence. As shown in the picture, in the same layer, there is a parallel Megatherium trackway. In addition, it contains Macrauchenia, Artiodactyla and flamingo trackways that cross the human one in different directions.

The evidence found in Pehuen Co allows us to consider two aspects. One of them is related to the activities people were carrying out in the site, the other is connected to the relation between this site and other South American sites assigned to the 

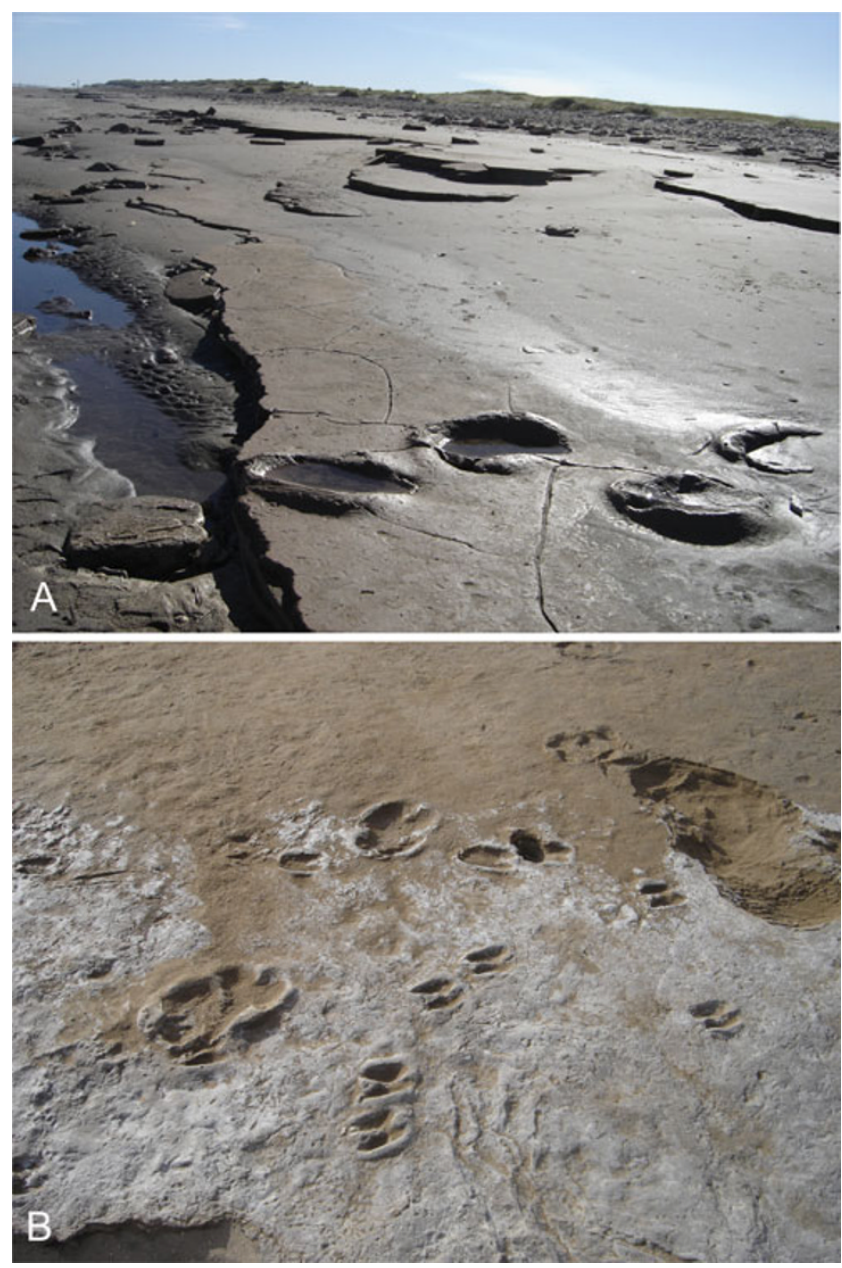

Fig. 7 Pehuen Co Palaeoichnological Site: a a layer with a Megatherium trackway; b Macrauchenia and guanaco footprints

latest Pleistocene. First, both the trackway and the loose footprints on isolated pieces show the transit of adult individuals, possibly in small groups, on the shores of freshwater bodies visited regularly by large mammals. This

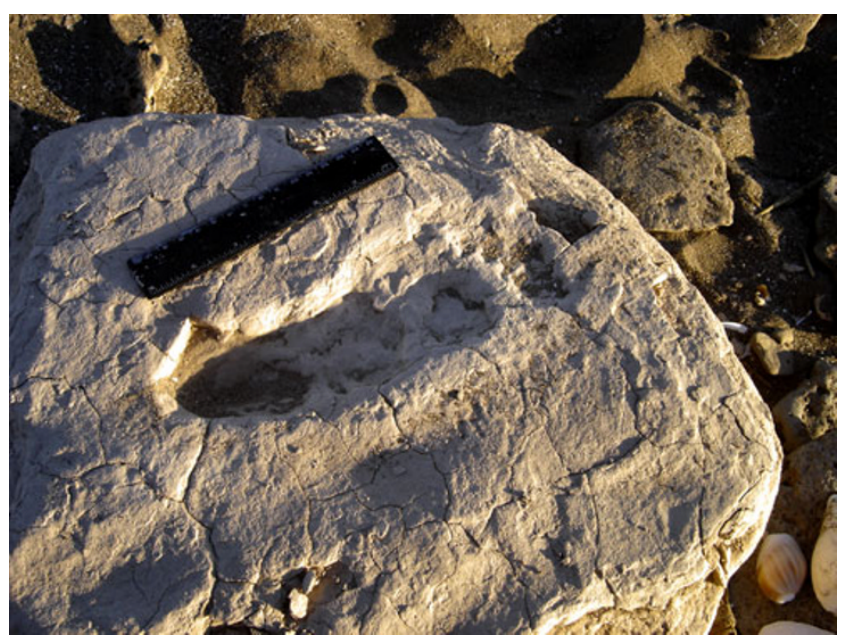

Fig. 8 Pehuen Co Palaeoichnological Site. Isolated human footprint

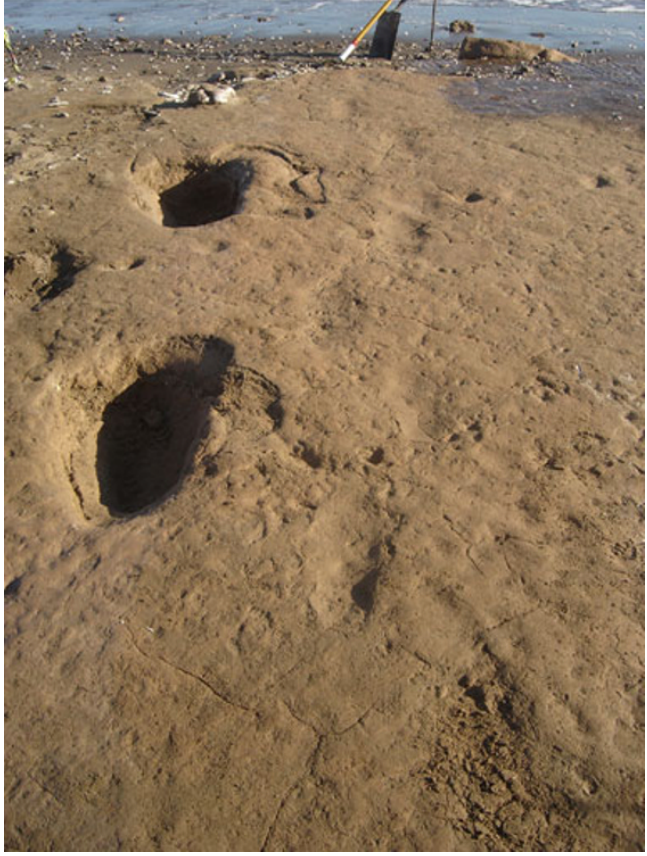

Fig. 9 Pehuen Co Palaeoichnological site: parallel trackways of the extinct giant ground sloth Megatherium and a human being, along with tracks of other animal species

scenario would be compatible with hunting events, in which the few hunters, usually men, scout around places where there are better chances of finding prey.

Second, these human traces are chronologically related to older evidence of the first settlers of the Pampean region of the Buenos Aires province. The archeological evidence of human presence of about $12.000{ }^{14} \mathrm{C}$ years BP are few and weak, not only in the region but in all America. The human sign of continuous occupation of the continent appears only at circa 12,500 years BP in the Monte Verde site in Chile (Dillehay 1997) and in Brazil (the recent dating of a human tooth in

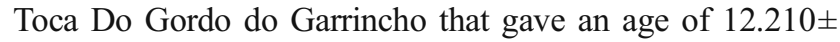
40; Peyre et al. 2009). In the Pampean region, there is a human signal, still feeble, at Arroyo Seco Site (130 kilometers northeast from Pehuen Co). At this site, some Pleistocene mammals were dated. Megatherium bones had marks of human action and were associated with stone tools, at circa 12,150 years BP (Steele and Politis 2009; Politis et al. in press, 2011). Another dating of Toxodon bone was estimated at $11,750{ }^{14} \mathrm{C}$ years $\mathrm{BP}$, although in this case no human action was verified. Finally, a third event was dated at ${ }^{14} \mathrm{C}$ years BP, which involves two equids present in the Pampean Latest Pleistocene: Equus and Hippidion. This event also exhibits evidence of human agency. It is important to highlight that the fauna of Arroyo Seco 2 dated between 12.150 and 11.200 BP also includes other genera, such as Glossoteherium and Paleolama; all are represented in the Pehuen Co ichnites, thus suggesting that both sites show similar faunal composition but in different kind of records. 
In the Pampean region, 16 sites dated during the Pleistocene-Holocene transition have been excavated in different settings. Pehuen Co human footprints would be included in this group. Ten of these sites are in caves, rock shelters, or open-air sites in the Tandilia hill range (Flegenheimer 2003; Mazzanti 2003; Mazzanti et al. 2010). The other six are located on plains near ponds or rivers (Flegenheimer et al. 2010; Martínez 2006; Politis and Messineo 2008). Probably both the sites in the Tandilia hill ranges and those in the surrounding plains are related. The majority of the occupations (12 sites) have a chronology between 11.000 and $9.000{ }^{14} \mathrm{C}$ years BP (Fig. 1). Although each site presents specific characteristics, the early huntergatherers share technological decisions as well as the good quality raw material selection strategies (Flegenheimer 2003). At some six of the sites, particular projectile points called "fishtail points" were found. This point is also present in other places in South America, also dated at the end of the Pleistocene (Flegenheimer et al. 2003; Nami 2007).

The settlements in the plains are characterized by being open-air sites and by the presence of Pleistocene megamammals remains. For example, in Arroyo Seco 2 (Fig. 1) giant ground sloths and extinct horses were processed and consumed, while in Paso Otero 5 (Fig. 1) the hunter-gatherers took advantage of Hemiauchenia and Megatherium and might even have used the bones as fuel (Martínez 2006). On the other hand, Pehuen Co site is indicative of the wandering of one or many hunters around a place with a variety of Pleistocene fauna. The presence of these large animals, represented either by their bones or footprints, suggests some kind of cooperative hunting strategy. It probably implies that there was an important number of individuals nearby who would be the potential consumers, either the hunters' families or the rest of the band (Politis 2008).

At the end of the Pleistocene, there was a particularly important event: the massive extinction of most of the megamammals whose footprints are found at Pehuen Co. The archeological and paleontological evidence of the region indicates that until circa 10,000 years BP, the Pampean grasslands supported an enormous biomass of large herbivores, which disappeared in a few thousand years. During the Late Pleistocene, $80 \%$ of mammals heavier than $44 \mathrm{~kg}$ and $100 \%$ of those heavier than $1000 \mathrm{~kg}$ were extinct (Owen-Smith 1987). Nevertheless, Pleistocene faunal remains (Megatherium and Doedicurus) whose radiocarbon dates indicate surprisingly recent ages were found in the Pampean plains in the $\mathrm{La}$ Moderna and Campo Laborde sites. These ages ranged between 7,500 and 8,000 ${ }^{14} \mathrm{C}$ years BP. Both sites (Fig. 1) have been interpreted as hunting/scavenging and primary butchering sites of very late mega-mammals on the shores of old swamps (Politis and Messineo 2008). These animals survived in the Pampean region for a few millennia within the Holocene (Gutiérrez and Martínez 2007; Politis and Messineo 2008).

What brought about the fast disappearance of the large and medium-sized mammal community? This topic has been extensively debated by different authors, and the answers vary from models that give human beings a central role in overkilling during the early stages of settlement (Cione et al. 2003; Martin 1984) to others who argue that the climatic and environmental changes were the main cause of the extinction (see summary in Haynes 2009). Some intermediate models propose either a minor role for human beings in the South American Pleistocene fauna extinction since the killing of these animals would have been occasional and opportunistic (Borrero 2009), or that the hunting would only have intensively affected the immigrant genera such as Equus and Hippidion and the Gomphoteridae Family (Politis et al. 1995). However, the evidence at Pehuen Co indicates that when the first human beings arrived in the Pampean region, most of the large- and medium-sized mammals were still alive. The evidence is too weak at this site to clarify the impact of these human beings on the Pampean animal community.

The Fourth Scenario: Monte Hermoso 1-La Olla $(1,2,4)$

At the beginning of the Middle Holocene, between 8,000 and 6,000 years BP, a new climatic change transformed the environment of the Pampean southwest. The cold and dry conditions, predominant during most of the final Pleistocene gave way to more moderate and mild conditions with more stability, characteristic of the beginning of the Holocene (Quattrocchio et al. 2008). Meanwhile, the sea level rose and the coast got closer to its present position (Fig. 2).

The archeological sites of Monte Hermoso 1 (MH1)-La Olla (with three discrete sectors LO 1, 2, and 4) are located

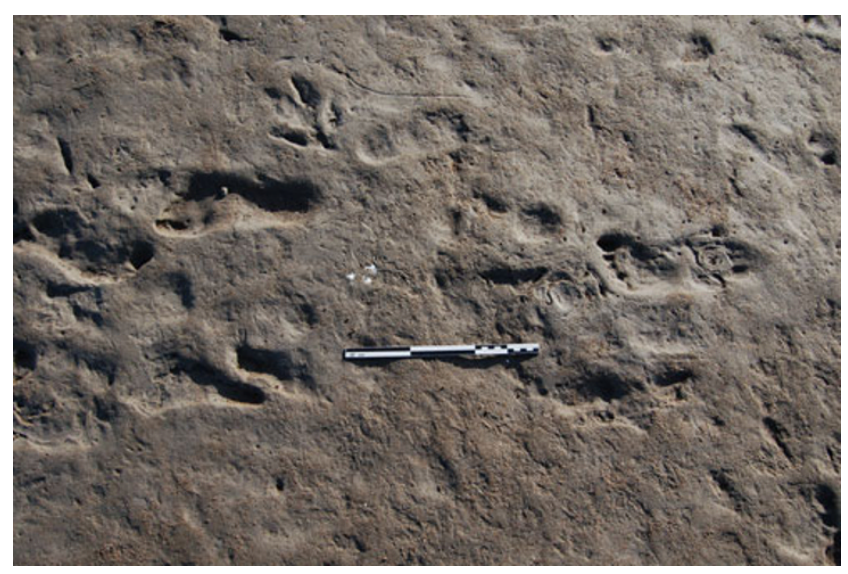

Fig. 10 Human footprints at Monte Hermoso 1 site 


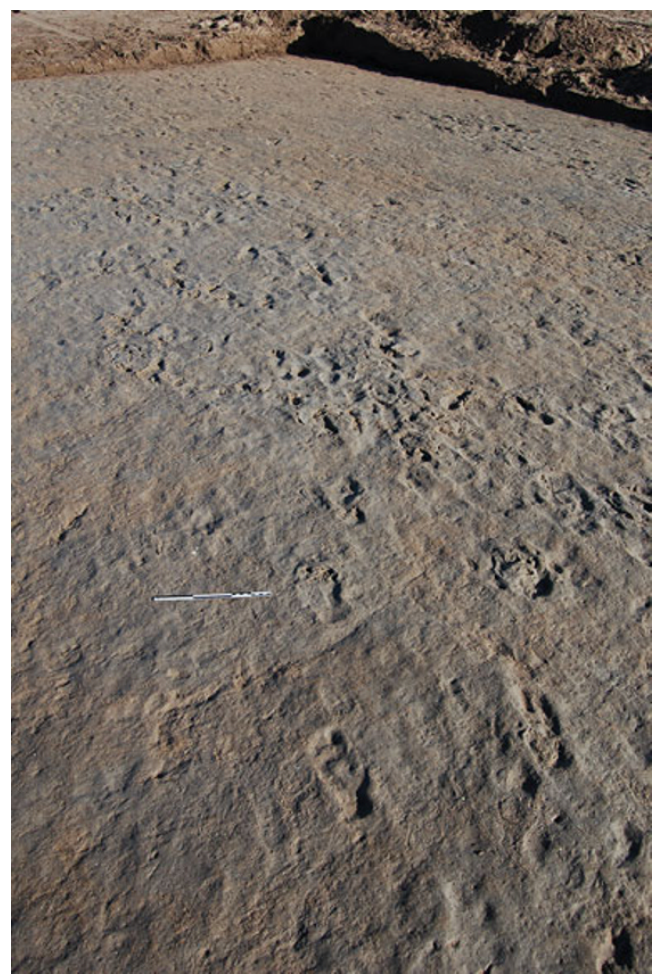

Fig. 11 Human trackway at Monte Hermoso 1 site

on the Atlantic coast, 15 kilometers east of Pehuen Co palaeoichnological site, near the town of Monte Hermoso. It extends 1,200 meters along the beach and is composed of stratigraphic deposits of overlaying levels of clay and sand formed in shallow water bodies with a certain degree of marine influence. The deposits present a variety of evidence of human occupation of the coast. The archeological site $\mathrm{La}$
Olla shows abundant faunal remains, as well as artifacts made on stone, bone and wood. On the other hand, in MH1, the archeological record is formed by numerous human, mammal, and bird footprints.

MH1 was located near an extinct lagoon between the dunes near the ocean surrounded by the typical humid interdune vegetation with slight marine influence (Zavala et al. 1992). The ostracode species are characteristic of environments of continental brackish water (Quattrocchio et al. 2008). On the other hand, the site LO1-2-4 is in a coastal marsh (Blasi MS 2010), with a predominantly halophyte vegetation. The ostracode species are typical of marine waters (Fontana 2005; Martínez et al. 2010; Quattrocchio et al. 2008). The vertebrate species present in these sites are those typical of the continental and marine Holocene fauna of the Pampean Region. There are 18 AMS radiocarbon dates from the site and two conventional ones which indicate that the marsh lasted between 7,920 and 6,600 years ${ }^{14} \mathrm{C}$ BP. Some of the dates come from marine mammals which have some reservoir effect not calculated yet.

Monte Hermoso 1 This site was located at the shore of the ancient interdune pond where hunter-gatherers carried out different activities (Bayón and Politis 1996). The several overlaying layers with footprints indicate that the place was periodically visited for hundreds of years. On the eastern sector of the site, there are hundreds of footprints (circa 472) of children, youths and women, who wandered around the pond shore while they gathered (probably plants and bird eggs; Fig. 10). Almost no artifacts have been found in this sector. In contrast, in the western sector of the site other

Fig. 12 La Olla,4 site in 2008 during low tide

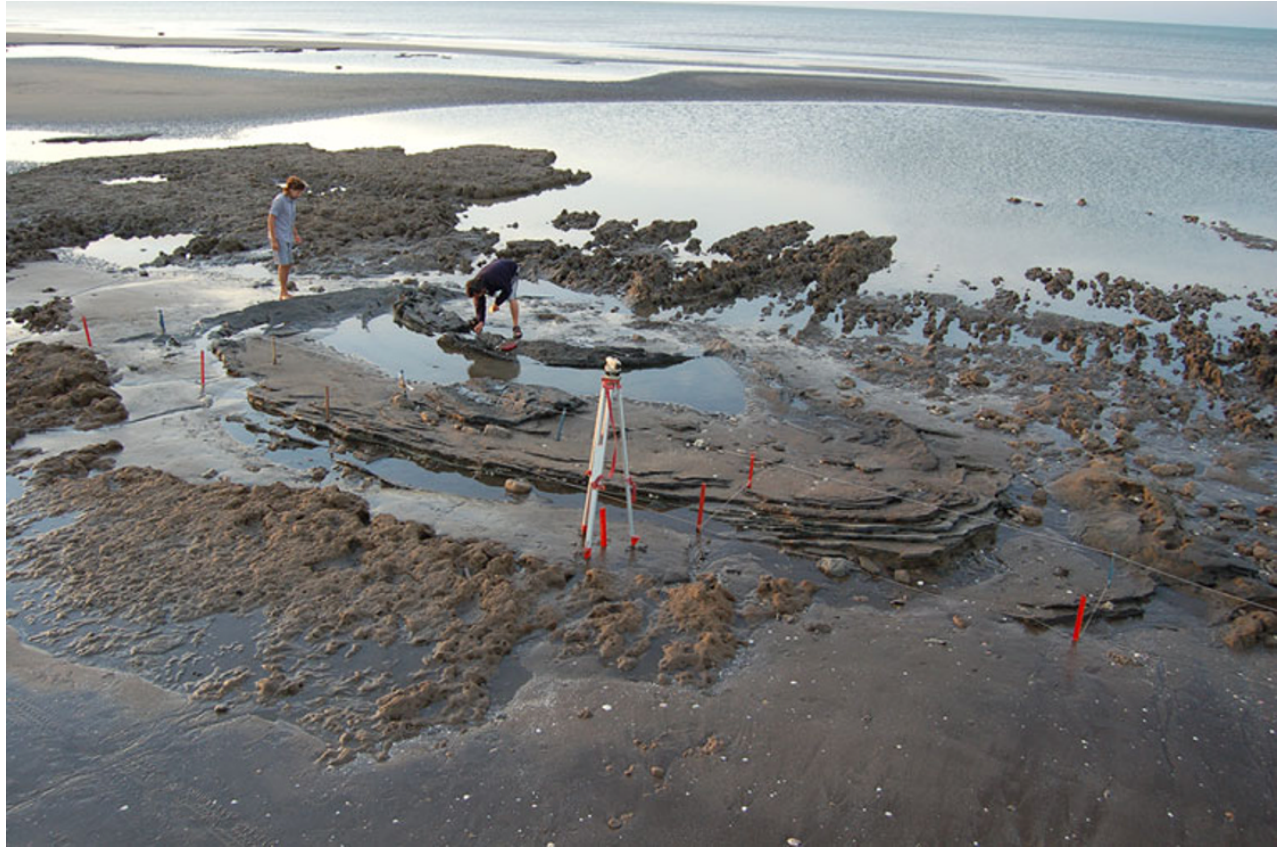


Fig. 13 Wooden tool

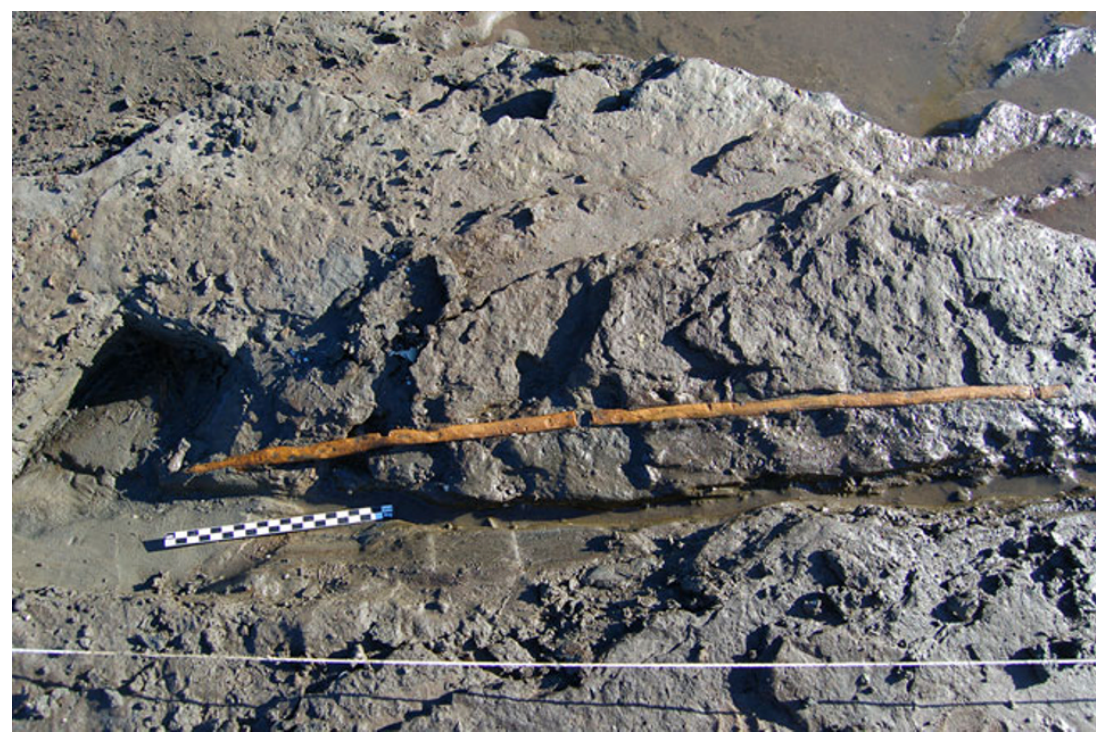

activities are recorded. There, faunal remains and lithic and wooden artifacts were found scattered in very low density. This context suggests an area outside a camp. The footprints found in this sector belong to adults (Fig. 11) with a predominantly SE-NO direction, suggesting a transit path. Also, human remains of two adult individuals (skull fragments and parts of limb bones) dated at $6,606{ }^{14} \mathrm{C}$ years BP and $7,886{ }^{14} \mathrm{C}$ years $\mathrm{BP}$ were found redeposited on the surface at the back of the beach. The stable isotope analysis $\left(\delta^{13} \mathrm{C}\right.$ coll; mean $=-13.4 \%$ of the human remains show remarkably enriched values, which indicates that marine foods were the basis of their diet (Politis et al. 2009). These findings were of great importance because they represent one of the few human remains of the Early-Middle Holocene from the coastal area of Argentina.

La Olla Is composed of three small outcrops (sectors 1-2-4) along 150 meters at the low tide line. They are usually covered with sand and have only been exposed, never simultaneously, five times in the last 20 years (Fig. 12). The archeological record is formed by abundant faunal remains and bone, wooden and lithic artifacts. Bones from two species of pinniped (Arctocephalus australis and Otaria byronia), guanaco (Lama guanicoe), deer (Ozotoceros bezoarticus), ostrich (Rhea americana), and fish were found. The two species of pinniped are the more abundant taxa present in the site ${ }^{1}$. Some elements present cut marks and combustion traces, while others were used to make expeditive tools (Johnson et al. 2000). The three sectors are interpreted as places where people finished the processing of the pinnipeds caught at the immediate marine coast. The stone tools are scarce, the raw material used in these

$\overline{{ }^{1} \text { For La Olla } 1}$ the NMI $=41$ individuals assemblages was of poor quality, and they were available among the Sauce Grande River pebbles. Most of them are marginal or unifacial artifacts, which were shaped with little investment. Wood was also processed, especially as raw material to make artifacts. The wooden artifacts are varied and comprise spears straightened and hardened with fire, a stone ax hafted with a wooden handle, and several other shaped pieces whose function is difficult to assess. The most surprising artifact is a long wooden spatula, decorated on both sides with zigzag engravings and red paint (Fig. 13). It is not possible to know about its use, but according to the type of instrument and decoration, it might have been connected to some kind of ritual activity. ${ }^{2}$

Both Monte Hermoso and the 1-La Olla site form a unique record in America, which also illustrates exceptionally the hunter-gatherers' way of life when the Atlantic coast drew closer, in the Pampean region between circa 7,600 and $6,600{ }^{14} \mathrm{C}$ years ago. On the coast of Monte Hermoso, the first signs of exploitation of marine resources were established. Also, these sites would be part of a nomadic circuit between the coast and the inland, which started at least in the Early Holocene and probably lasted until the very Late Holocene (Bonomo 2005).

\section{Final Considerations}

On the southwest edge of the Pampean region, four important moments in the evolution of the landscape, of the animal

\footnotetext{
${ }^{2}$ It was put under a colophony treatment for its conservation by Alberto Orsetti, in Centro de Arqueología Urbana de la Ciudad de Buenos Aires lab.
} 
communities and of the human settlements of South America are exceptionally represented. Farola Monte Hermoso cliff clearly shows continental sediments containing remains of Miocene-Pliocene mammals, members of the native fauna that inhabited Southamerica before The Great American Biotic Interchange. This mammal association is very important and served as the basis to define an evolutionary stage named Monthermosean Stage/Age. This cliff also has a great historic and heritage value: Darwin extracted the fossils there that made an early impact on his "transmutationist" ideas, and in front of them Florentino Ameghino and Ales Hdrlička hotly debated on the age of the "American Man."

At the Playa del Barco site, there is a faunal association composed of both South American native fauna and North American immigrants. The native fauna is represented by some groups that were present at the Farola Monte Hermoso site but with different and more modern genera. This environment was still not altered by human beings, and it would represent the scene that the first huntergatherers faced when they arrived in the region.

A turning point in the history of life in South America is represented in Pehuen Co: probably the last megamammal footprints are here together with those of the first human beings who populated the region. The end of the Pleistocene (circa 12,000 years BP) was a crucial moment beyond which the Pampean region physiognomy changed: a few thousand years later, none of these megamammals whose footprints filled Pehuen Co remained, and the plains were covered with hunter-gatherer bands that intensively exploited much smaller animals, such as the guanaco and the pampas deer.

During the Early Holocene, between circa 7,000 and 6,500 ${ }^{14} \mathrm{C}$ year BP, almost immediately after the last giant ground sloths and glyptodonts were extinct, the hunter-gatherers began to exploit intensively the coastal resources, especially the sea mammals, and they left hundreds of their footprints at water bodies near the beach. This exceptional record is complemented with the finding of wooden instruments, a type of technology previously unknown in the Pampean archeological record. All these considerations make this part of the Pampean region an extraordinary place to understand the evolutionary processes in South America within a wide scale. Also, it presents a unique record which allows us to have a clearer view of these key four moments in the environmental evolution of the continent.

\section{References}

Ameghino F. Monte Hermoso. Buenos Aires: Imprenta de Pablo Coni e Hijos; 1887.

Ameghino F. La Industria de la Piedra Quebrada de Monte Hermoso. Obras Completas y correspondencia científica de Florentino Ameghino. Vol. XVIII. La Plata: Taller de Impresiones Oficiales; 1934 [1910]. p. 391-7.
Aramayo SA, de Manera Bianco T. Edad y nuevos hallazgos de icnitas de mamíferos y aves en el yacimiento paleoicnológico de Pehuen Co (Pleistoceno tardío). Publicación Especial 41 Reunión Argentina de Icnología: Provincia de Buenos Aires, Argentina Asociación Paleontológica Argentina; 1996. p. 47-57.

Aramayo SA, de Manera Bianco T. Primer hallazgo de icnitas de mamíferos pleistocenos en "Playa del Barco", Pehuen Co, Provincia de Buenos Aires, Argentina. Ameghiniana. Suplemento Resúmenes. 2000;37(4): 19 .

Aramayo SA, Manera de Bianco T. Nuevos hallazgos de mamíferos pleistocénicos en el Yacimiento de Playa del Barco, Provincia de Buenos Aires. Actas, Primeras Jornadas Geológicas Bonaerenses (1985 )Tandil: 1989;701-12.

Bayón C, Politis G. Estado actual de las investigaciones en el Sitio Monte Hermoso 1 (Prov. de Buenos Aires). Arqueología. 1996;6:83-115.

Bayón C, Zavala C. Coastal sites in south Buenos Aires: A review of Piedras Quebradas. Quaternary of South America and Antartic Peninsula. In: Rabassa J, Salemme M, editors. Vol 10: 229-253. A. A. Bookfield: BalkemaL Rotterdam; 1997.

Blasi A. MS, Informe geológico del sitio La Olla. Facultad de Ciencias Naturales y Museo. UNLP. La Plata. 2010

Bonomo M. Archaeology and human interaction between coastal and inland settings: the Pampean Atlantic coast, Argentina. Before Farming 2005(3), article 3. 2005.

Borrero L. The elusive evidence: the archeological record of the South American extinct megafauna. In: Haynes G, editor. American megafaunal extinctions at the end of the Pleistocene. New York: Springer Science; 2009. p. 145-68.

Cione AL, Tonni EP, Soibelenzon L. The broken zig-zag: Late Cenozoic large mammals and tortoises extinction in South America. RevArg del Mus de Cs Nat ns. 2003;5(1):2-19.

Dillehay TD. Monte Verde: a Late Pleistocene settlement in Chile. The archaeological context and interpretation, Vol. 2. Washington, DC: Smithsonian Institution Press; 1997.

Eldredge N. Darwin lives! A World of Science. 2009;7(4):2-9.

Flegenheimer N. Cerro el Sombrero: a locality with a view. Ancient Evidence for Paleo South Americans: from where the south winds blow. In: Miotti L, Salemme M, Flegenheimer N (editors) Editor in Chief: R. Bonnichsen. Center for the Study of the First Americans. Texas: Texas University Press; 2003. pp. 51-6.

Flegenheimer N, Bayón C, Valente M, Baeza J, Femeninas J. Long distance tool stone transport in the Argentine Pampas. Quaternary International, guest editors L. Miotti and M. Salemme. The Journal of the INQUA. 2003;109-110:49-64.

Flegenheimer N, Bayón C, Pupio A. LLegar a un nuevo mundo. Arqueología de los primeros pobladores del actual territorio argentino, Ed. Antropofagia, Buenos Aires, $2^{\text {a }}$ ed. 2007.

Flegenheimer N, Bayón C, Scabuzzo C, Mazzia N, Vecchi R, Weitzel C, Frontini R, Colombo M. Early Holocene human skeletal remains from the Argentinean Pampas. Current Research in the Pleistocene 2010;27:10-12.

Fontana S. Holocene vegetation history and palaeoenvironmental conditions on the temperate Atlantic coast of Argentina, as inferred from multi-proxy lacustrine records. J Paleolimnol. 2005;34:445-69.

Gutiérrez MA, Martínez GA. Trends in the faunal human exploitation during the Late Pleistocene and Early Holocene in the Pampean region (Argentina). Quatern Int. 2007;191:53-68.

Haynes G, editor. American megafaunal extinctions at the end of the Pleistocene. New York: Springer; 2009.

Johnson E, Politis G, Gutierrez M. Early Holocene bone technology at the Coastal La Olla 1 site along the Pampas seashore of Argentina. J Archaeol Sci. 2000;27:463-77.

Manera de Bianco T, Aramayo SA, Zavala C, Caputo R. Yacimiento Paleoicnológico de Pehuen Co. Un patrimonio 
natural en peligro. Sitios de Interés Geológico, Comisión Sitios de Interés Geológico de la República Argentina, Instituto de Geología y Recursos Minerales, Servicio Geológico Minero Argentino (Eds). Buenos Aires: Artes Gráficas Papiros; 2008. pp. 509-20.

Marshall LG, Hoffstetter R, Pascual R. Mammals and stratigraphy: Geochronology of the continental mammal-bearing Tertiary of South America. Palaeovertebrata, Montpellier. Mem Extr 1983;1-93.

Martin P. Prehistoric overkill: the global model. Quaternary extinctions: a prehistoric revolution. In: Martin PS, Klein RG (editors) University of Arizona Press; 1984. pp. 354-403.

Martínez G. Arqueología del curso medio del río Quequén Grande: Estado actual y aportes a la arqueología de la Región Pampeana. Relaciones de la Sociedad Argentina de Antropología 2006;XXXI:249-75.

Martínez D, Jiménez L, Bayón C, Politis G. Sitios arqueológicos del Holoceno de la costa sur de la provincia de Buenos Aires: los ostracódos como indicadores paleoecológicos Congreso Argentino de Paleontología y Bioestratigrafía y VII Congreso Latinoamericano de Paleontología. Argentina: La Plata; 2010.

Mazzanti DL. Human settlements in caves and rockshelter during the Pleistocene-Holocene in the Eastern of Tandilia Range, Pampean Region, Argentina. Ancient evidence for Paleo South Americans: from where the South Winds blow. In: Miotti L, Salemme M, Flegenheimer N (editors) Editor in Chief: R. Bonnichsen. Center for the Study of the First Americans. Texas: Texas University Press; 2003. pp. 57-61.

Mazzanti D, Colobig M, Zucol FA, Martínez G, Porto López J, Brea $\mathrm{M}$, et al. Investigaciones arqueológicas em el sitio 1 de la localidad Lobería 1. Mamül Mapu pasado y presente desde la arqueología Pampeana. In: Berón M, Luna L, Bonomo M, Montalvo C, Aranda C, Carrera Aizpitarte y M (editors) Editorial Libros del Espinillo, Ayacucho; 2010. pp. 99-114.

Nami H. Research in the Middle Rio Negro Basin (Uruguay) and the Paleoindian Occupation of the Southern Cone. Curr Anthropol. 2007;48(1):164-74.

Owen-Smith RN. Pleistocene extinctions: the pivotal role of megaherbivores. Paleobiology. 1987;13:351-62.

Peyre A, Granat J, Guidon N. Dents et cranes humains fossiles du Garrincho (Brasil) et peuplements anciens de l'Amerique. Actes Societe francaise d'histoire de l'art dentaire. 2009;14:32-7.

Politis G. The Pampas and Campos of South America. In: Silverman H, Isbell W (editors) Handbook of South American Archaeology. New York: Springer; 2008. pp. 235-60.

Politis GG, Gutierrez M, Scabuzzo C (editors). Estado actual de las investigaciones arqueológicas en el sitio Arroyo Seco 2 (Pdo. de Tres Arroyos, Pcia. de Buenos Aires, Argentina). Serie Monográfica INCUAPA nro 4. Olavarría 2011, In press.
Politis GG, Messineo PG. The Campo Laborde site: new evidence for the Holocene survival of Pleistocene megafauna in the Argentine pampas. Quatern Int. 2008;191:98-114.

Politis G, Prado JL, Beukens R. The Human Impact in PleistoceneHolocene extinctions in South America-The Pampean Case. In: Johnson E, editor. Ancient Peoples and Landscapes. Museum of Texas Tech University: Lubbock, Texas; 1995.

Politis G, Scabuzzo C, Tykot R. An approach to prehispanic diets in the pampas during early/middle Holocene. Int J Osteoarchaeol. 2009;19:266-80.

Pupio A, Bayón C, Vecchi R. Buscando las pruebas para el Darwinismo. F. Ameghino en Monte Hermoso. "Workshop Bridging the Gap...Darwin from molecule to cultural implications". 10-12 de Octubre Bahía Blanca. 2009.

Quattrocchio M, Borromei AM, Deschamps CM, Grill SC, Zavala CA. Landscape evolution and climate changes in the Late Pleistocene-Holocene, southern Pampa (Argentina): evidence from palynology, mammals and sedimentology. Quatern Int. 2008;181:123-38.

Quattrocchio M, Deschamps CM, Zavala CA, Grill SC, Borromei AM. Geology of the area of Bahía Blanca, Darwin's view and the present knowledge: a story of 10 million years. Revista de la Asociación Geológica Argentina. 2009;64(1):137-46.

Simpson GG. History of the fauna of Latin America. Am Sci. 1950;38:361-89.

Steele J, Politis G. AMS ${ }^{14} \mathrm{C}$ dating of early human occupation of southern South America. J Archaeol Sci. 2009;36:419-29.

Tomassini RL, Montalvo CI, Manera T, Oliva C. Estudio tafonómico de los mamíferos pleistocenos del yacimiento Playa del Barco (Pehuen Co), provincia de Buenos Aires, Argentina. Ameghiniana. 2010;47(2):137-52.

Zavala C. Estratigrafía de la localidad de Farola Monte Hermoso (Plioceno-Reciente), provincia de Buenos Aires. Actas $12^{\circ}$ Congreso Geológico Argentino y $2^{\mathrm{a}}$ Congreso de Exploración de Hidrocarburos 1993;2:228-35.

Zavala C, Quattrocchio M. Estratigrafía y evolución geológica del río Sauce Grande (Cuaternario), provincia de Buenos Aires, Argentina. Asociación Geológica Argentina, Revista. 2001;56(1):25-37.

Zavala C, Grill S, Martínez D, Ortiz H, González R. Análisis paleoambiental de depósitos cuaternarios. Sitio Paleoicnológico Monte Hermoso I, Provincia de Buenos Aires. Actas de las Terceras Jornadas Geológicas Bonaerenses: 31-37. La Plata. 1992

Zavala C, García L, Di Meglio M. Redes de drenaje y paleoclimas en el Cuaternario del sur de la provincia de Buenos Aires. XVI Congreso Geológico Argentino, CD-ROM, 2005; paper No 156. 2 pp. La Plata. 2005. 